
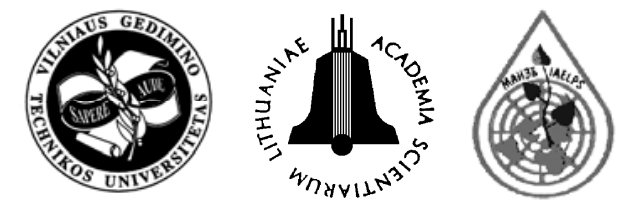

JOURNAL OF ENVIRONMENTAL ENGINEERING AND LANDSCAPE MANAGEMENT

\title{
SUBSURFACE CHEMICAL DISCHARGE IN LITHUANIAN AREA
}

\author{
Jonas Diliūnas ${ }^{1}$, Danutė Karveliené ${ }^{2}$, Arūnas Jurevičius ${ }^{3}$ \\ Climate and Water Research Dept, Institute of Geology and Geography, Nature Research Centre, \\ T. Ševčenkos g. 13, LT-03223 Vilnius, Lithuania \\ E-mails: ${ }^{1}$ diliunas@geo.lt; ${ }^{2}$ karveliene@geo.lt; ${ }^{3}$ arunas@geo.lt
}

Submitted 25 Sep. 2009; accepted 11 Feb. 2010

\begin{abstract}
An assessment of groundwater chemical leakage under the Lithuanian hydrogeological conditions, using the classic method of hydrogeological/ hydrograph division and linking it with the chemical leakage. Subsurface chemical discharge is the amount of salts flown by the rivers due to their draining impact on the subsurface. The chemical runoff is determined by two key factors: groundwater runoff yield and total content of dissolved solids (TDS). The value of the groundwater runoff module (the yield from $1 \mathrm{~km}^{2}$ ) in the river basins of Lithuania ranges from 0.4 to $5.0 \mathrm{l} / \mathrm{s} \mathrm{km}$. TDS values in shallow groundwater drained by the rivers range from 180 to $800 \mathrm{mg} / \mathrm{l}$. The modules of subsurface chemical runoff in the area of Lithuania range from 3-9 to $54 \mathrm{t} / \mathrm{year}$ from $1 \mathrm{~km}^{2}$ with the highest values observed in the Baltija uplands and Dainava Plain. During the last decade, the chemical runoff has stabilised due to decline in technogenic load. If compared to the dissolved solids drained by the rivers the subsurface chemical discharge can make up $7-45 \%$. The chemical runoff out for all area of Lithuania, as assessed by the hydrological/hydrogeological technique according to the minimum long-term runoff and TDS content in the river water of that period, reaches $2.2 \mathrm{mln}$. t/year of mineral material, about $90 \%$ of which come from the Nemunas River basin. To restrict the influence of technogenic pollution on the results of the assessment of underground chemical runoff, only observations done upstream the pollution sources (mainly urban) have been used. The qualitative assessment of the changes in groundwater chemical discharge and flow fluctuations due to technogenic impact has been carried out by applying graphical analysis of the underground chemical runoff module.
\end{abstract}

Keywords: groundwater runoff modulus, total dissolved solids, subsurface chemical discharge modulus, environmental conditions.

\section{Introduction}

The aim: assessment of groundwater chemical leakage under the Lthuanian hydrogeological conditions, using the classic method of hydrogeological/hydrograph division and linking it with the chemical leakage. The subsurface chemical runoff is the amount of salts contained in water and entering the rivers or other surface water bodies in a certain time due to the draining impact of the rivers on the subsurface. The subsurface chemical runoff is also called the ion runoff, since its calculation is based on concentrations of basic anions and cations $\left(\mathrm{HCO}_{3}{ }^{-}, \mathrm{Cl}^{-}\right.$, $\mathrm{SO}_{4}{ }^{2-}, \mathrm{Ca}^{2+}, \mathrm{Mg}^{2+}, \mathrm{Na}^{+}, \mathrm{K}^{+}$) dissolved in groundwater, because they make the major part of total dissolved solids (TDS) in fresh water. The comparative analysis of the subsurface chemical runoff from a limited area enables to assess and prognosticate the changes in groundwater quality and environmental and human-made factors determining these changes.

To assess the subsurface chemical runoff, the data available at the Lithuanian Geological Survey (chemical regime observation data), long-term observations done at the Lithuanian Hydrometeorological Service and the Environment Protection Agency database (river monitoring hydrochemistry analyses and wastewater discharge and quality) have been used. The results of the chemical analysis data presented are based on the river hydrochemical monitoring data from 29 posts during the period of 1985-2003 (Fig. 1).

\section{Methods}

The subsurface chemical runoff is assessed by a hydrological/hydrochemical method that is based on the product of groundwater runoff volume and river water total dissolved solids (TDS). During a dry period, the river runoff is basically formed by groundwater; therefore, the amount of chemical substances carried by a river can be taken as equal to the subsurface chemical runoff that is composed of two components: river water yield and TDS content during a dry-weather period. Therefore, to determine the chemical runoff for a river basin, it is necessary to have representative characteristics of the groundwater runoff module to be calculated from the latest data on hydrological regime observations and subsurface runoff data published earlier in the literature.

The subsurface runoff into the rivers is most often assessed by a complex hydrological/hydrogeological hydrograph separation method to determine average annual (normal) indices or precipitation recharge calculation method according to the groundwater table observation data (Барисас, Игнатавичюс 1969; Сакалаускене 1969; Simniškaitè 1968; Lasinskas 
1994). The groundwater runoff into the rivers of the Nemunas basin is mainly formed (about 90\%) from the Quaternary aquifers (shallow and first confined ones), whereas the active draining effect of rivers does not exceed 70-100-m depths.

The hydrological regime of the Nemunas basin rivers is rather consistent, therefore the groundwater runoff, as determined by the classical hydrological/hydrogeological hydrograph separation method is rather reliable and can be compared to other hydrological characteristics.

The hydrological regime of the rivers in the northern part of Lithuania, especially karst area, is considerably more complicated (Lasinskas 1994), therefore here the assessment of groundwater runoff to rivers is rather complicated task. In the case of contradictory values of groundwater runoff (Simniškaite 1968) or lacking literary data, the values of summer-autumn normal yield modulus for 30 driest days were used. Moreover, applying longterm normal runoff (Gailiušis et al. 2001; Многолетние... 1987), the ratio of groundwater input into the river and total river runoff was determined.
The subsurface chemical discharge modulus was calculated by the following formula:

$$
M_{u g}=\frac{Q_{u g} \cdot T D S_{u g}}{F_{b}} \cdot 0.032,
$$

$M_{u g}$ - modulus of subsurface chemical discharge from the river basin, t/year $/ \mathrm{km}^{2} ; Q_{\text {ug. }}$ - groundwater runoff through a river section or the summer-autumn yield for 30 driest days, $1 / \mathrm{s} ; T D S_{u g}$. total dissolved solids content in river water, mg/l, at the minimum yields corresponding to the groundwater runoff; $\mathrm{F}_{\mathrm{b}}$ - area of the rive basin, $\mathrm{km}^{2}$.

The analysis of the relationship between the river enabled to find that the best way to assess the chemical runoff is to use the TDS content since the correlation coefficient for the largest rivers is at least 0.6 (Fig. 2) (Diliūnas, Karvelienè 2004). Therefore all been done on the basis of the total dissolved solids content that embraces many key chemical elements (Ca, $\mathrm{Na}, \mathrm{Mg}, \mathrm{HCO}_{3}, \mathrm{Cl}$, $\left.\mathrm{SO}_{4}\right)$.

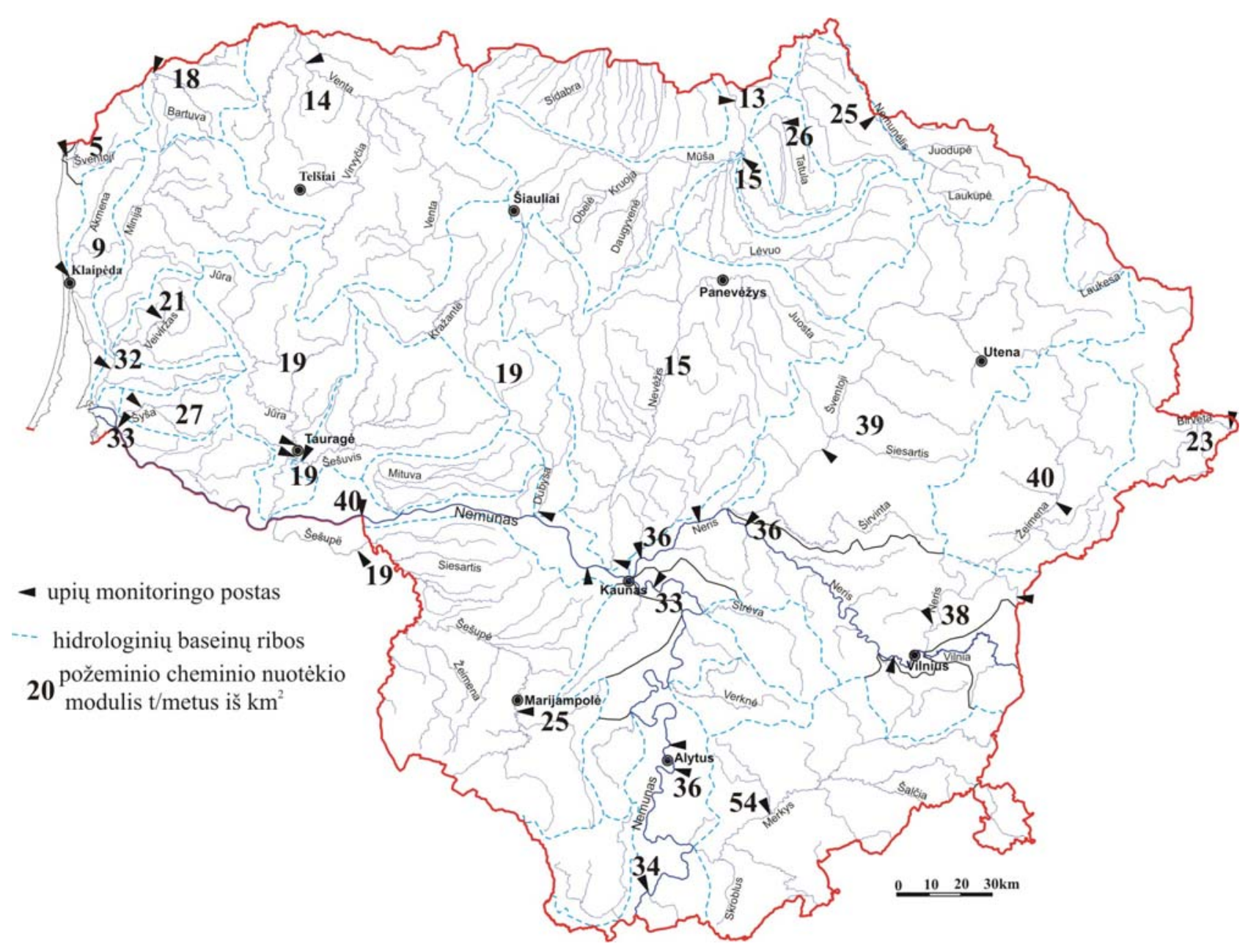

Fig. 1. Distribution of subsurface chemical discharge modulus in the main Lithuanian river basins 

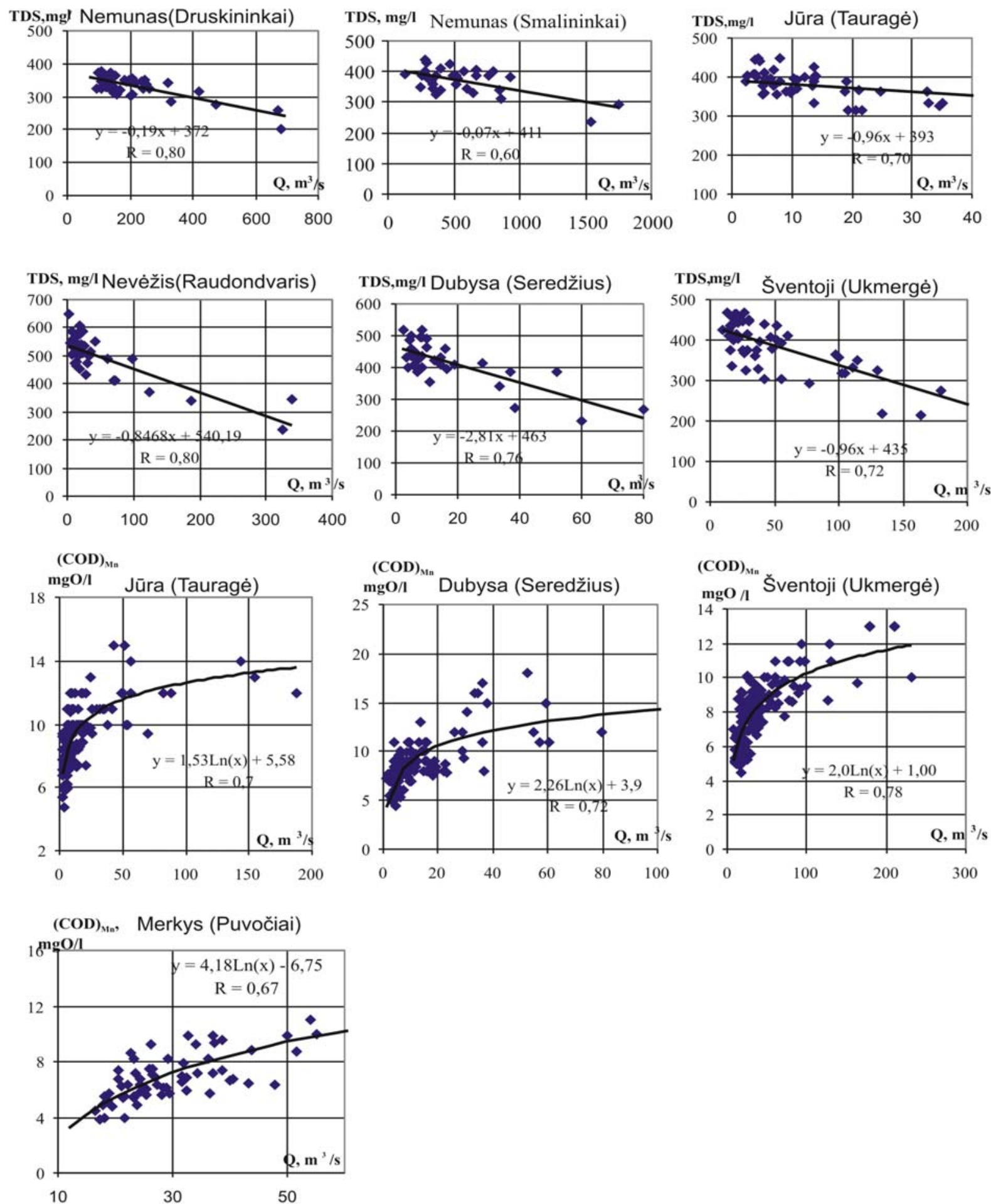

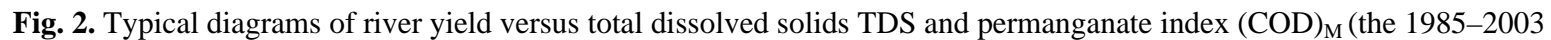
environmental monitoring data)

The content of organic matter expressed by permanganate index $(\mathrm{COD})_{\mathrm{Mn}}$ is reckoned to be an indicator of river water pollution. It grows with the growing river water yield, i.e. during the periods when organic matterpolluted surface water enters a river. The correlation coefficient for organic matter in SE Lithuania ranges from 0.5 to 0.9 for different water level periods (BagdžiūnaitèLitvinaitienè 2004). To study the river water minimum runoff and chemistry, the observation data upstream from the pollution sources (mainly, towns) have been used. The effect of river water pollution on the calculation results was assessed in a differentiated way according to the data provided by Environmental Ministry about the wastewater discharge into the rivers and water pollution upstream and downstream the pollution sources. The study results showed that this effect was not high, i.e. 
TDS at the points upstream and downstream the towns differed just 1-7\% (Diliūnas, Karvelienè 2004). Such small difference might be caused by the increase in chemical runoff due to surface pollution of river water.

In order to distinguish surface water flow yields and chemical composition balance units, typical climatic periods have been chosen. They characterise spring melting when the rivers are fed with water most intensively, as well as summer-autumn and winter low water feed. To calculate the amounts of dissolved salts the volume of groundwater runoff for dry season is multiplied by TDS. In order to get more precise subsurface chemical discharge, the summer runoff data of the TDS in river water is a bit lower due to snow meltwater input (Tilickis 2005).

The Environmental Research Centre was, as a rule, performing the determination of TDS content at their river observation posts 4 times a year. The TDS value taken for chemical runoff calculations was chosen by several approaches. First of all, all TDS values for minimum yields in summer-autumn dry period were selected; then, the relationship between the TDS content and groundwater runoff was determined and the values of hydrochemical analyses were used, since in winter the pursued indices calculated. This relationship is most often necessary to be determined in the cases when the subsurface feed is not obvious (the Nevěžis River).

When the minimum yields are lower than that for the 30 driest summer days, the TDS-Q $\mathrm{Qmin}_{\text {in }}$ trend is not well expressed. In this case, the average TDS content (the Neris River) was taken for calculations of the chemical runoff (Fig. 3). As a rule, this value corresponds to that of TDS in shallow groundwater.
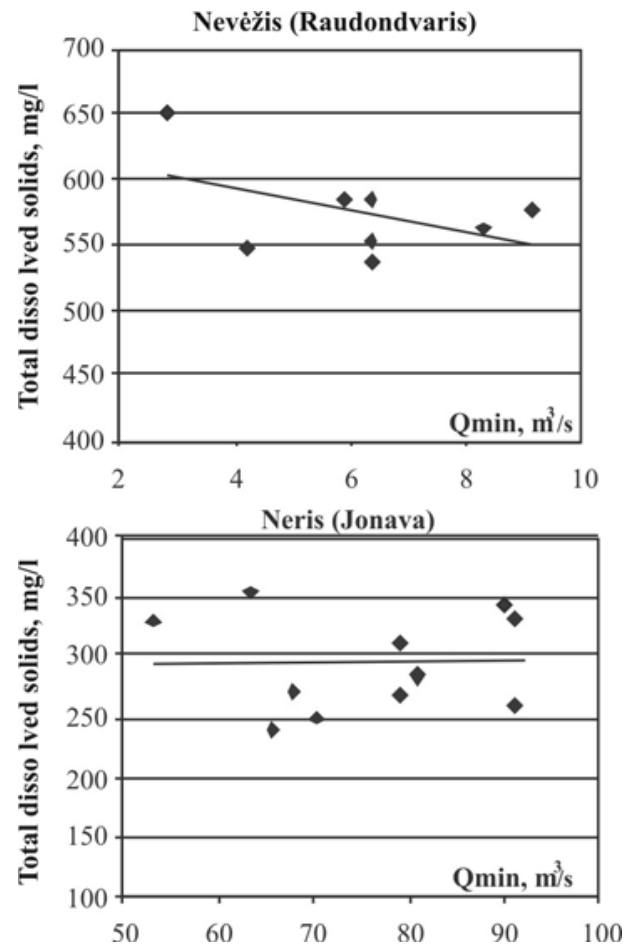

Fig. 3. Examples of diagrams for total dissolved solids (TDS) versus minimum river yield
The formula (1) was used to determine the groundwater yields in time (1985-2003), which were studied when creating the diagrams and looking for change trends.

The data of the river monitoring posts situated at the river mouths or border zones were used to determine the total chemical runoff and its subsurface part from all Lithuanian area. The runoff volume formed in the area of Lithuania was taken from literature (Meilutytè-Barauskienè et al. 2008).

\section{Results}

The modulus of groundwater runoff determined by hydrological/hydrogeological methods is given in Table 1, where one more hydrological parameter is also presented - the normal yield for 30 driest days. This parameter determined for a warm period was used, when it is 1.2-3 times higher than that for an analogous winter period (Lasinskas 1994). Minimum runoff value is greatly affected by duration of the dry period and minimum precipitation level. Barisas and Ignatavičius (Барисас, Игнатавичюс 1969) showed the relationship between the 30 driest summer day yield and river feed by groundwater. Table 1 shows that the minimum normal yield is identical to the groundwater runoff modulus. The low summer season runoff is caused by several factors as is the groundwater runoff (Barisas 1981; Januškis 1981). The groundwater runoff modulus or the summer 30 day minimum yield modulus coefficients depend on water abundance of the year. There are cases mentioned in the literature (Akmena River), when this coefficient determined for the wet period of 1977-1991 is twice or even more higher than the normal one (Tilickis 2005). At the background of climate changes, the dry season runoff for Lithuanian rivers was analysed by D. MeilutyteBarauskienè et al. (2008) and the conclusion was made that the rise in runoff was observed only in the western part of Lithuania, as it was caused by a very wet 19781990 period. In general, there were no trends in minimum runoff variations determined in the rest of Lithuania.

The groundwater runoff modulus is affected by the following physico-geographical factors: geological setting, water-bearing rock lithology, river incision depth, possibility of rainfall input from land surface etc. Major shallow groundwater resources and groundwater runoff are formed in glaciofluvial (fIII), alluvial (aIV), alluvial+intermorainal (a+agIII-II), marine (mIV), aeolian (vIV), glacial base (gIII) and marginal (g III) moraines, glaciolacustrine (lgIII) and organogenic (bIV) deposits (Juodkazis and Mikalauskas 1994). Typical hydrogeological schemes of the structure of these waterbearing beds is shown in Fig. 4, and parameters of groundwater runoff and recharge are given in Table 2, where the average regional groundwater runoff values are presented. 
Table 1. Groundwater runoff modulus and summer-autumn yields in 30 driest days

\begin{tabular}{|c|c|c|c|c|c|c|c|c|c|}
\hline \multirow[t]{2}{*}{ River } & \multirow[t]{2}{*}{ Post } & \multirow{2}{*}{$\begin{array}{l}\text { Area, } \\
\mathrm{km}^{2}\end{array}$} & \multirow{2}{*}{$\begin{array}{c}\begin{array}{c}\text { Normal } \\
\text { runoff }\end{array} \\
\mathrm{m}^{3} / \mathrm{s}\end{array}$} & \multicolumn{3}{|c|}{$\begin{array}{c}\text { Groundwater runoff (Барисас, Игна- } \\
\text { тавичюс 1969) }\end{array}$} & \multicolumn{3}{|c|}{$\begin{array}{c}\text { Summer-autumn yield in } 30 \text { driest } \\
\text { days (Gailiušis et al. 2001) }\end{array}$} \\
\hline & & & & $\begin{array}{c}\text { Observation } \\
\text { period }\end{array}$ & $\mathrm{m}^{3} / \mathrm{s}$ & $\begin{array}{l}\text { modulus } \\
\mathrm{l} / \mathrm{s} \mathrm{km}^{2}\end{array}$ & $\begin{array}{c}\text { Observation } \\
\text { period }\end{array}$ & $\mathrm{m}^{3} / \mathrm{s}$ & $\begin{array}{l}\text { modulus } \\
1 / \mathrm{s} \mathrm{km}^{2}\end{array}$ \\
\hline \multicolumn{10}{|c|}{ Nemunas basin } \\
\hline \multirow[t]{4}{*}{ Nemunas } & Druskininkai & 37100 & 212 & 1945-1962 & 112.0 & 3.0 & 1945-1996 & 115.0 & 3.1 \\
\hline & Nemaniūnai & 42800 & 265 & & 146.0 & 3.4 & 1920-1996 & 148.0 & 3.5 \\
\hline & Kaunas & 46300 & 298 & 1929-1959 & 150 & 3.2 & 1947-1959 & 164.0 & 3.5 \\
\hline & Smalininkai & 81200 & 540 & 1811-1962 & 251 & 3.1 & 1893-1959 & 261.0 & 3.2 \\
\hline \multirow[t]{2}{*}{ Merkys } & Varèna & 2830.0 & 24.3 & 1957-1965 & 16.0 & 5.6 & 1955-1971 & 15.3 & 5.33 \\
\hline & Puvočiai & $\begin{array}{l}4220.0 \\
4300^{1)} \\
\end{array}$ & 35.3 & 1966-1967 & 23.0 & 5.4 & $1951-1996^{1)}$ & 23.3 & 5.42 \\
\hline \multirow[t]{3}{*}{ Neris } & Buivydžiai & 11100 & 71.6 & & & & 1967-1996 & 39.5 & 3.6 \\
\hline & Vilnius & 15200 & 111 & 1945-1964 & 55.5 & 3.7 & 1923-1996 & 62.1 & 4.1 \\
\hline & Jonava & 24600 & 178 & 1920-1962 & 93.5 & 3.8 & 1920-1996 & 91.5 & 3.7 \\
\hline Žeimena & Pabradè & 2580 & 21.2 & 1954-1962 & 12.7 & 4.9 & 1959-1996 & 12.0 & 4.65 \\
\hline Šventoji & Ukmergè & 5440 & 40.8 & 1951-1965 & 15.9 & 2.9 & 1954-1996 & 15.6 & 2.87 \\
\hline \multirow[t]{2}{*}{ Nevėžis } & Kèdainiai & 3230 & 16.7 & 1925-1960 & 1.20 & 0.4 & 1948-1960 & 1.97 & 0.61 \\
\hline & Dasiūnai & $\begin{array}{c}5440 \\
5530^{2)}\end{array}$ & 27.2 & 1960-1962 & 2.2 & 0.4 & $1961-1996^{2)}$ & 4.53 & 0.82 \\
\hline Dubysa & Padubysis & 1840 & 13.5 & 1929-1962 & 2.39 & 1.3 & 1945-1996 & 3.21 & 1.74 \\
\hline \multirow[t]{2}{*}{ Šešupè } & Marjampolè & 1930 & 8.91 & 1937-1962 & 2.91 & 1.5 & 1968-1996 & 2.39 & 1.24 \\
\hline & Dolgoje $^{3)}$ & 5830 & 32.6 & & 7.0 & 1.2 & 1956-1991 & 6.28 & 1.08 \\
\hline Jūra & Tauragè & 1690 & 21.0 & 1945-1962 & 2.38 & 1.4 & 1956-1996 & 3.46 & 2.05 \\
\hline Šešuvis & Skirgailiai & 1880 & 15.4 & 1939-1962 & 1.73 & 0.92 & 1946-1996 & 2.34 & 1.24 \\
\hline Minija & Kartena & 1230 & 15.1 & 1924-1962 & 3.02 & 2.5 & 1962-1996 & 3.06 & 2.49 \\
\hline Veiviržas & Mikužiai & 358 & 4.49 & 1954-1962 & 0.55 & 1.5 & 1954-1996 & 0.50 & 1.49 \\
\hline Šyša & Jonaičiai & 174 & 2.03 & 1959-1964 & 0.19 & 1.1 & 1960-1996 & 0.34 & 1.95 \\
\hline \multicolumn{10}{|c|}{ Venta basin } \\
\hline Venta & Papilè & 1570 & 9.97 & & & & 1956-1996 & 1.70 & 1.08 \\
\hline Venta & Leckava & 4060 & 30.6 & & & & 1951-1996 & 5.19 & 1.28 \\
\hline \multicolumn{10}{|c|}{ Daugava basin } \\
\hline $\begin{array}{c}\text { Svyla } \\
\text { (Birvetos) }\end{array}$ & Guntauninkai & 148 & 0.86 & & & & 1963-1996 & 4.46 & 2.23 \\
\hline \multicolumn{10}{|c|}{ Rivers in Lithuanian maritime area } \\
\hline Bartuva & Skuodas & 612 & 6.61 & & & & 1957-1996 & 0.79 & 1.29 \\
\hline $\begin{array}{l}\text { Akmena- } \\
\text { Dané }\end{array}$ & Tubausiai & 196 & 2.31 & & & & $1962-1991$ & 0.12 & 0.61 \\
\hline Šventoji & Večiai & 35.8 & & & & & 1957-1966 & 0.015 & 0.42 \\
\hline \multicolumn{10}{|c|}{ Mūša-Nemunèlis basin } \\
\hline Nemunèlis & Rimšiai & 877 & 5.93 & & & & 1958-1985 & 1.15 & 1.31 \\
\hline Mūša & Ustukiai & 2280 & 10.3 & & & & 1958-1996 & 1.31 & 0.57 \\
\hline Tatula & Trečionys & 404 & 2.73 & & & & $1962-1996$ & 0.59 & 1.46 \\
\hline Lėvuo & Pasvalys & 1560 & 6.58 & & & & $1951-1996$ & 1.38 & 0.88 \\
\hline
\end{tabular}

${ }^{1)}$ with outflow via Merkys-Voke canal determined, ${ }^{2)}$ with input from Lèvuo and Šventoji determined, ${ }^{3)}$ water measurement post in Kaliningrad district (Russia).

The highest values of groundwater runoff modulus were observed for upland areas, where sand prevails in the Quaternary section and the rugged relief creates favourable conditions for groundwater to discharge into the river network (Merkys, Žeimena and Šešupè, Šventoji and Minija upper reaches). Shallow groundwater in east and southeast Lithuania is observed mainly in glaciofluvial deposits (sand with gravel and cobble occurring as deep as $50 \mathrm{~m}$. The ice marginal incisions play a significant role in groundwater feed of the rivers, since there are conditions favourable for seepage from deeper aquifers. The groundwater feed in the river runoff makes $30-65 \%$. 

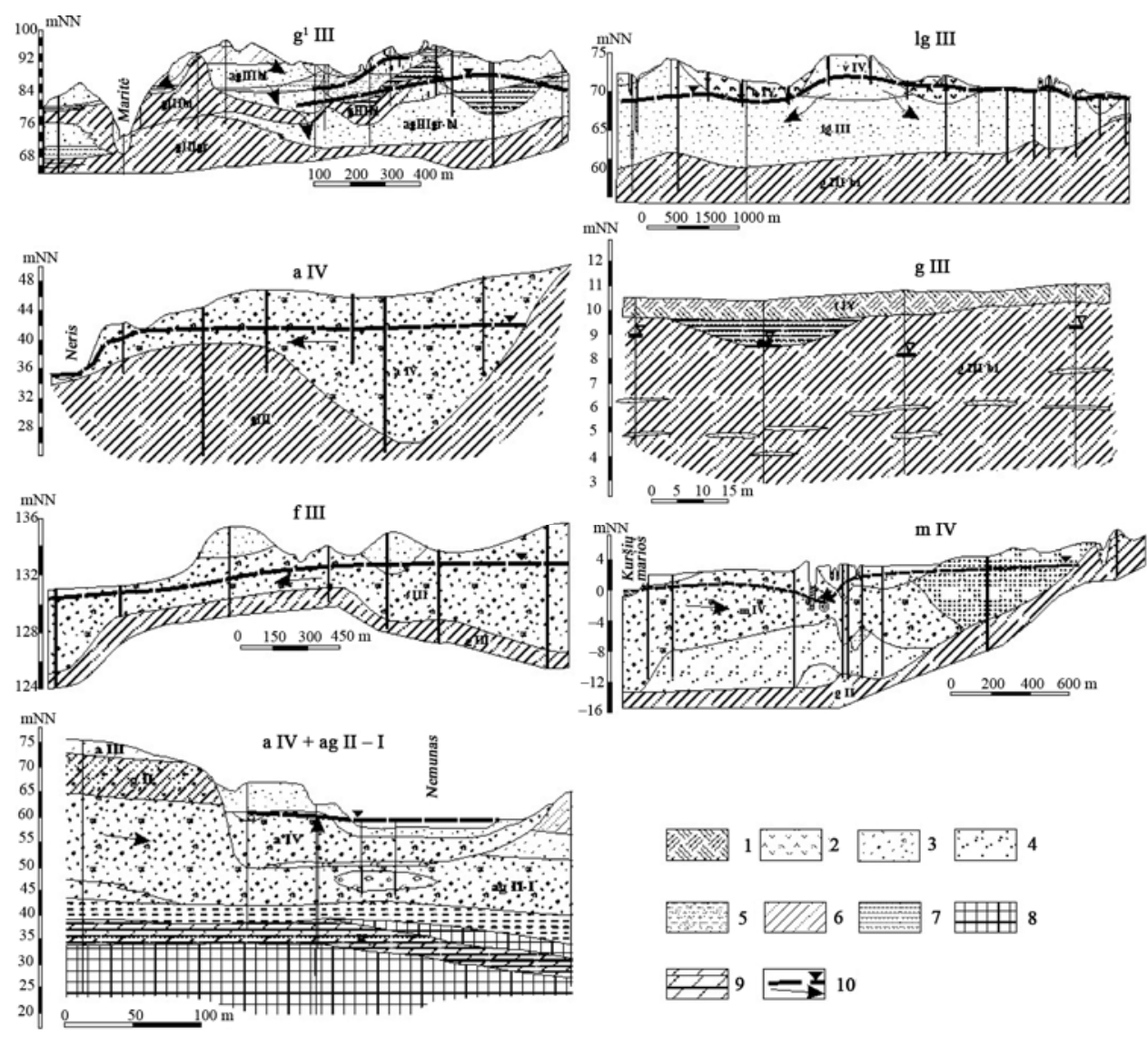

Fig. 4. Schemes of groundwater genetic types and hydrogeological conditions: 1 - technogenic soil, 2 - peat, 3 - coarse sand, 4 - fine sand, loam, 5 - clayey sand, 6 - loam, 7 - clay, 8 - chalk, 9 - marl, 10 - groundwater table and flow direction

Table 2. Groundwater runoff (Сакалаускене 1969)

\begin{tabular}{l|c|c}
\hline \multicolumn{1}{c|}{ Aeration zone deposits and geological index } & $\begin{array}{c}\text { Groundwater runoff } \\
\text { modulus l/s km }{ }^{2}\end{array}$ & $\begin{array}{c}\% \text { of } \\
\text { precipitation }\end{array}$ \\
\hline Glaciolacustrine clay (lg III), peat (bIV) & $-7-0$ & $-35-0$ \\
\hline $\begin{array}{l}\text { Glacial loam and sandy loam (gIII, gtIII), Glaciolacustrine sandy loam (lgIII), } \\
\text { alluvial (aIV), marine (mIV), mire (bIV) and aeolian (vIV) fine sand }\end{array}$ & $0-1.0$ & $0-5.0$ \\
\hline $\begin{array}{l}\text { Alluvial (aIII), marine (mIV), lacustrine (IV), glaciolacustrine (lgIII) and } \\
\text { glaciofluvial (fIII) various-grained sand }\end{array}$ & $1.0-5.0$ & $5.0-25.0$ \\
\hline Alluvial (aIII), (aIV) and glaciofluvial (f III) various-grained sand and gravel & $5.0-9.0$ & $25.0-45.0$ \\
\hline Glaciofluvial (f III) and glacioaquatic (agIII, agtIII) sand, gravel and pebble & $>9.0$ & $>45.0$ \\
\hline
\end{tabular}

Different conditions take place in the recent plains, where there are lower reaches of most rivers. These plains are mainly formed of till loam with rare sand beds or interlayers. The aquifers do not bear a continuous character and are rather thin. Shallow groundwater accumulates in the upper part of the weathered till loam beds at the 3-4 m depths. The plain relief and low permeability retard the groundwater runoff. Therefore, the lowest groundwater runoff values are observed there. Thus, the groundwater runoff in the Central Lithuanian Plain (basins of Nevėžis, and Šešupè), the Maritime Plain (Akmena-Danè, Šventoji) and north Lithuania (MūšaNemunèlis) makes, respectively $17-20 \%$, up to 5\% and $13-20 \%$ of the total.

The key factors determining chemistry of shallow groundwater are genetic types of soil and water-bearing deposits, water exchange rate, interrelation of aquifers and intensity of anthropogenic load (Arustienè 2006, 2004; Kondratas 2001; Pocienè, Pocius 2005). Water exchange rate in the active zone, where draining effect of a river takes place, depends on such conditions as the position in regard to geomorphological regions, deposit lithology etc. Under natural conditions due to intensive recharge, fresh water with low content of TDS (0.4$0.6 \mathrm{~g} / \mathrm{l}$ ) and of calcium-magnesium hydrocarbonate type is formed. The lowest TDS content is observed in shallow groundwater of sandy deposits in the upland areas. Zones of shallow groundwater with a higher content of TDS coincides with the area of clayey formations, where the exchange rate is lower and the water washes more mineral substances from the deposits. 
Table 3. Extreme river yields (Q) (1985-2003) and corresponding total dissolved solids (TDS) as well as groundwater TDS in the active exchange zone

\begin{tabular}{|c|c|c|c|c|c|c|c|c|}
\hline \multirow[t]{2}{*}{ River } & \multirow[t]{2}{*}{ Post } & $\begin{array}{c}\mathrm{Q}_{\mathrm{MIN}}, \\
\mathrm{m}^{3} / \mathrm{s}\end{array}$ & $\begin{array}{l}\text { TDS, } \\
\text { mg/l }\end{array}$ & $\begin{array}{c}\mathrm{Q}_{\mathrm{MIN}} \\
\mathrm{m}^{3} / \mathrm{s}\end{array}$ & TDS, mg/l & $\begin{array}{c}\mathrm{Q}_{\mathrm{MAX}} \\
\mathrm{m}^{3} / \mathrm{s}\end{array}$ & TDS, mg/l & \multirow{2}{*}{$\begin{array}{l}\text { Groundwater TDS in } \\
\text { intensive exchange } \\
\text { zone }{ }^{* * *}, \mathrm{mg} / \mathrm{l} \\
\text { (Mičiudienė 1991) }\end{array}$} \\
\hline & & \multicolumn{2}{|c|}{$\begin{array}{c}\text { summer-autumn low } \\
\text { water }\end{array}$} & \multicolumn{2}{|c|}{ winter low water } & \multicolumn{2}{|c|}{ spring melting period } & \\
\hline Jūra & u. ${ }^{* *}$ Tauragè & 2.4 & 388.2 & 5.3 & 356.0 & 143.0 & 253.7 & $350-510$ \\
\hline Dubysa & u.Seredžius & 2.4 & 518.0 & 5.1 & 434.6 & 79.8 & 269.0 & $470-650$ \\
\hline Šventoji & u.Ukmergè & 9.5 & 425.1 & 18.0 & 400.3 & 210.0 & 323.9 & $410-460$ \\
\hline Nevėžis & u.Raudondvaris & 2.8 & 651.0 & 6.4 & 552.0 & 340.0 & 342.6 & $320-480$ \\
\hline Šešupè & u.Marijampolè & 1.7 & 492.4 & 3.1 & 523.9 & 51.8 & 310.7 & $470-800$ \\
\hline Merkys & Puvočiai & 17.4 & 305.7 & 16.5 & 320.4 & 76.0 & 265.1 & $210-350$ \\
\hline Žeimena & u.Pabradè & 11.9 & 304.4 & 13.8 & 342.5 & 39.3 & 295.7 & $180-300$ \\
\hline Venta & d.**Mažeikiai & 2.9 & 473.4 & 4.9 & 469.2 & 210.0 & 380.4 & $360-840$ \\
\hline Mūša & Saločiai & 1.4 & 745.9 & 5.4 & 648.6 & 98.7 & 489.1 & $960-1100$ \\
\hline Tatula & u.Biržai & 0.17 & 598.1 & 0.2 & 576.6 & 17.8 & 517.7 & $570-880$ \\
\hline Lèvuo & u.Pasvalys & 0.8 & 650.8 & 1.5 & 598.4 & 27.7 & 460.3 & $790-1400$ \\
\hline Nemunas & u.Druskininkų & 98.0 & 371.5 & 110.0 & 376.2 & 694.0 & 335.9 & $360-400$ \\
\hline Nemunas & Smalininkai & 244.0 & 350.9 & 128.0 & 392.1 & 1750 & 292.2 & $390-580$ \\
\hline Neris & u.Vilnius & 43.8 & 322.6 & 52.4 & 370.0 & 270.0 & 273.3 & $410-600$ \\
\hline Neris & u.Jonava & 63.8 & 352.9 & 86.9 & 335.2 & 1000.0 & 248.5 & $260-470$ \\
\hline Minija & d.Priekulè & 0.59 & 420.6 & 3.0 & 400.7 & 113.0 & 293.5 & $380-730$ \\
\hline Bartuva & d.Skuodas & 0.38 & 447.0 & 1.45 & 427.1 & 34.5 & 400.1 & $330-950$ \\
\hline
\end{tabular}

* $\mathrm{Q}_{\mathrm{MIN}}$ - river minimum yield; $\mathrm{Q}_{\mathrm{MAX}}$ - river maximum yield; ** $\mathrm{u}$ - upstream measurement post, d - downstream the post; *** depth zone of intensive exchange-groundwater draining by rivers.

The closest relationship of river yield and TDS content in the water was obtained during its linear approximation-the TDS content declines when the river water is additionally fed by the atmospheric precipitation. During the summer dry periods, the TDS content in river water corresponds closely to that in the aeration zone groundwater (shallow and upper confined aquifers) in the drained basins (Table 3). Therefore, in order to assess the subsurface chemical discharge, the parameters of summer dry-weather period have been chosen. The parameters of subsurface chemical discharge from the main river basins of Lithuania are given in Table 4 and Fig. 1.

In Lithuania the highest values of subsurface chemical runoff $\left(\mathrm{t} / \mathrm{year} / \mathrm{km}^{2}\right)$ from the Nemunas basin rivers were found for the Merkys basin, followed by the basins of Neris and Žeimena, where the runoff reaches 40 $50 \mathrm{t} /$ year $/ \mathrm{km}^{2}$. This is due to considerably higher groundwater runoff yields. In central Lithuanian clayey plains, even at higher TDS content in groundwater, the chemical runoff decrease depends mainly on groundwater runoff yield. The north Lithuanian river (Mūša, Nemunèlis and Venta) basins, where groundwater runoff modulus is low, the chemical runoff modulus values (from 12 to $25 \mathrm{t} /$ year $/ \mathrm{km}^{2}$ ) grow due to higher TDS content in the water. Similar chemical runoff data are observed in the river basins situated in the Maritime Plain and Žemaitija Upland's northern and western parts (rivers of Minija and Bartuva). Based on the hydrochemical data available for 1985-2003, the calculations of subsurface chemical runoff showed its stability or decrease in time. The groundwater runoff at many monitoring posts in the rivers of
Nemunas and Neris is notable for a decrease trend. As mentioned above, the minimum runoff in 1961-2003 showed no distinct trends in its variation.

Such a phenomenon was observed also during the examination of chemical runoff variations. In this case, the key role was played by total dissolved solids (TDS).

The changes in subsurface chemical discharge were, undoubtedly, affected by technogenic load in the whole area of Lithuania. Higher values of chemical discharge at the beginning of the period studied were caused by considerably more intensive economic activities. In a course of all the period of observations, the trends in chemical runoff for some river basins were caused by natural and technogenic factors affecting the chemistry of groundwater (shallow aquifers, first of all). In time, the areas with this effect being unchanged showed the trend of chemical runoff stability (Mūša, Akmena-Danè, Šešupè); the areas where this effect decreased showed the trend of chemical runoff modulus decrease or stabilisation (Neris, Merkys, Dubysa, Jūra, Nevėžis etc.) (Fig. 5). The chemical runoff modulus for the Nemunas River water was rather stable during the all period studied; i.e., hydrochemical properties of water in different basins are similar (Diliūnas, Karvelienè 2004). On this basis a methodological conclusion can be made that the variations in water chemistry are best revealed if they are examined and assessed in concrete regions (river basins). From 2003, hydrocarbonate ions $\left(\mathrm{HCO}_{3}{ }^{-}\right)$are not being determined at the river monitoring posts; therefore, total dissolved solids cannot be calculated. Thus the investigations of groundwater inflow into the rivers encounter difficulties. 
The subsurface chemical runoff from the Nemunas basin in Lithuania had been investigated previously by A. Kondratas (1968, 1969, 2001). In many cases, the values of this runoff obtained by him exceeded considerably (3-4 times) those given in the present paper. This difference can be explained by the lack of hydrochemical data, since sometimes only two-year measurement data were used for calculations. The larger array of data smooth down the variations in TDS values and large differences in groundwater runoff modulus.

Total chemical runoff from the Lithuanian area has been calculated by using the data on average long-term runoff from the main river basins (Meilutyte-Barauskiene et al. 2008) or by assessing the total dissolved solids (TDS) in the river water as an average of the data collected during the period of 1985-2003. Chemical runoff data are presented below in Table 5.

Table 4. Subsurface chemical discharge calculation results

\begin{tabular}{|c|c|c|c|c|c|c|c|}
\hline \multirow[t]{2}{*}{ River } & \multirow[t]{2}{*}{ Post } & \multirow{2}{*}{$\begin{array}{c}\text { Area, } \\
\mathrm{km}^{2}\end{array}$} & \multirow{2}{*}{$\begin{array}{c}\text { Qug., } \\
\text { l/s }\end{array}$} & \multirow{2}{*}{$\begin{array}{c}\text { TDS }_{\text {ug }} \\
\mathrm{mg} / \mathrm{l}\end{array}$} & \multicolumn{3}{|c|}{ Chemical discharge $\left(\mathrm{M}_{\mathrm{ug}}\right)$} \\
\hline & & & & & $\mathrm{mg} / \mathrm{s}$ & t/year & $\mathrm{t} /$ year $/ \mathrm{km}^{2}$ \\
\hline \multicolumn{8}{|c|}{ Nemunas basin } \\
\hline \multirow[t]{5}{*}{ Nemunas } & *u. Druskininkai & 37100 & 115000 & 344 & 39560000 & 1265920 & 34.12 \\
\hline & u. Alytus & 42590 & 136200 & 357 & 48623400 & 1555949 & 36.53 \\
\hline & u. Kaunas & 46300 & 150000 & 320 & 48000000 & 1536000 & 33.17 \\
\hline & Smalininkai & 81200 & 251000 & 400 & 100400000 & 3212800 & 39.57 \\
\hline & u. Rusnè & 92390 & 251000 & 380 & 112480000 & 3599360 & 38.96 \\
\hline Merkys & Puvočiai & 4300 & 23300 & 310 & 722300 & 231136 & 53.75 \\
\hline \multirow[t]{4}{*}{ Neris } & Buivydžiai & 11100 & 39500 & 338 & 13351000 & 427232 & 38.49 \\
\hline & u. Vilnius & 15200 & 62100 & 327 & 20306700 & 649814 & 42.75 \\
\hline & Jonava & 24600 & 93500 & 294 & 27489000 & 879648 & 35.76 \\
\hline & u. Kaunas & 24898 & 94600 & 300 & 28380000 & 908160 & 36.48 \\
\hline Žeimena & u. Pabradè & 2580 & 12000 & 270 & 3240000 & 103680 & 40.19 \\
\hline Šventoji & u. Ukmergè & 5440 & 15600 & 430 & 6708000 & 214656 & 39.46 \\
\hline Nevėžis & u. Raudondvaris & 6100 & 5000 & 580 & 2900000 & 92800 & 15.21 \\
\hline Dubysa & u. Seredžius & 1972 & 2563 & 450 & 1153350 & 36907 & 18.72 \\
\hline \multirow[t]{2}{*}{ Šešupé } & u. Marjampolè & 1730 & 2910 & 470 & 1367700 & 43766 & 25.30 \\
\hline & Dolgoje & 5830 & 7000 & 500 & 3500000 & 112000 & 19.21 \\
\hline Jūra & u. Tauragé & 1690 & 2500 & 400 & 1000000 & 32000 & 18.93 \\
\hline Šešuvis & Skirgailiai & 1880 & 2340 & 480 & 1123200 & 35942 & 19.12 \\
\hline Minija & *d. Priekulè & 2600 & 6500 & 404 & 2626000 & 84032 & 32.32 \\
\hline Veiviržas & Veiviržènai & 104 & 160 & 420 & 67200 & 2150 & 20.68 \\
\hline Šyša & d. Šilutè & 125 & 240 & 450 & 108000 & 3456 & 27.65 \\
\hline \multicolumn{8}{|c|}{ Venta basin } \\
\hline Venta & d. Mažeikiai & 3689 & 3700 & 440 & 1628000 & 52096 & 14.12 \\
\hline \multicolumn{8}{|c|}{ Lithuanian maritime rivers } \\
\hline Bartuva & d. Skuodas & 612 & 790 & 440 & 347600 & 11123 & 18.18 \\
\hline Akmena-Danė & mouth & 580 & 354 & 480 & 169920 & 5437 & 9.37 \\
\hline Šventoji & mouth & 472 & 200 & 400 & 80000 & 2560 & 5.42 \\
\hline \multicolumn{8}{|c|}{ Mūša-Nemunèlis basin } \\
\hline Nemunèlis & d. Rimšiai & 877 & 1150 & 600 & 690000 & 22080 & 25.18 \\
\hline Mūša & d. Saločiai & 5090 & 2900 & 690 & 2001000 & 64032 & 12.58 \\
\hline Tatula & u. Biržai & 180 & 263 & 560 & 147280 & 4713 & 26.18 \\
\hline Lèvuo & u. Pasvalys & 1560 & 1380 & 520 & 717600 & 22963 & 14.72 \\
\hline \multicolumn{8}{|c|}{ Daugava basin } \\
\hline Birveta & Pasienis & 822 & 250 & 330 & 82500 & 2640 & 3.21 \\
\hline
\end{tabular}

$*_{\mathrm{u}}$ - upstream the post; $\mathrm{d}$ - downstream; F - total area of basin; $\mathrm{Qug}_{\mathrm{ug}}$ - groundwater runoff through a river section or the summer-autumn yield for 30 driest days. 

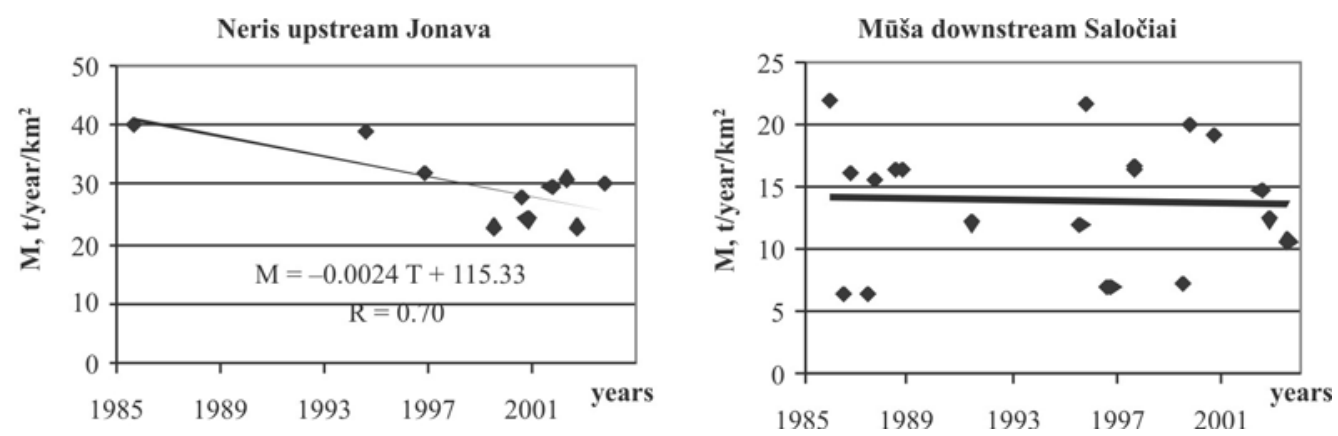

Fig. 5. Subsurface chemical discharge variations in the basins of the Neris and Mūša rivers

Table 5. Chemical runoff (M) from Lithuanian area

\begin{tabular}{|c|c|c|c|c|c|}
\hline \multirow[t]{2}{*}{ River basins } & \multirow{2}{*}{$\begin{array}{c}\text { Average annual runoff, } \mathrm{km}^{3} \\
\text { (Meilutytė-Barauskienè et al. 2008) }\end{array}$} & \multirow{2}{*}{$\begin{array}{c}\mathrm{TDS}_{\mathrm{av}}, \\
\mathrm{mg} / \mathrm{l}\end{array}$} & \multicolumn{2}{|c|}{ Chemical runoff, t/year } & \multirow[t]{2}{*}{$\mathrm{M}_{\mathrm{ug}} / \mathrm{M}_{\mathrm{T}}$} \\
\hline & & & total $\left(\mathrm{M}_{\mathrm{T}}\right)$ & subsurface $\left(\mathrm{M}_{\mathrm{ug}}\right)$ & \\
\hline \multicolumn{6}{|c|}{ In Lithuania’s area } \\
\hline Nemunas basin & 12.117 & 360 & 4362120 & 1968304 & 0.45 \\
\hline \multicolumn{6}{|c|}{ Runoff into Kuršių Marios (Curonian Lagoon) and the Baltic Sea } \\
\hline Šventoji & 0.147 & 345 & 50715 & 2560 & 0.05 \\
\hline Akmena-Danė etc. & 0.318 & 450 & 143100 & 5437 & 0.04 \\
\hline \multicolumn{6}{|c|}{ Runoff from Lithuania to neighbouring states } \\
\hline Daugava tributaries & 0.256 & 320 & 81920 & 5971 & 0.07 \\
\hline Nemunèlis & 0.437 & 600 & 205390 & 47634 & 0.23 \\
\hline Mūša & 0.768 & 600 & 460800 & 66636 & 0.14 \\
\hline Lielupè small tributaries* & 0.275 & 800 & 220000 & 24203 & 0.11 \\
\hline Venta & 1.261 & 400 & 504400 & 72587 & 0.14 \\
\hline Bartuva & 0.282 & 426 & 120132 & 13595 & 0.11 \\
\hline Total: & & & 6148577 & 2206928 & 0.36 \\
\hline
\end{tabular}

The total chemical runoff from the main river basins in Lithuania's area makes about $6.2 \mathrm{mln}$. t/year, including $70 \%$ from the Nemunas basin and about $27 \%$ to the neighbouring countries. A share of subsurface chemical runoff makes about $36 \%$ of the total runoff consisting of subsurface and surface chemical runoff. The subsurface chemical runoff from the Nemunas basin makes $46 \%$, whereas that from the maritime rivers and basins of Mūša and Venta is from several to $10 \%$.

\section{Conclusions}

1. River runoff during a dry-weather period is mainly formed by groundwater; thus, the amount of chemical substances transported by rivers can be treated identical to subsurface chemical runoff. The most reliable assessment of chemical runoff is based on total dissolved solids (TDS) content, which relates the sum of key chemical elements $\left(\mathrm{Ca}, \mathrm{Na}, \mathrm{Mg}, \mathrm{HCO}_{3}, \mathrm{Cl}\right.$, and $\mathrm{SO}_{4}$ ) and minimum summer-autumn dry period yields. The average total values of the parameters calculated are determined on the basis of the relationship between the TDS and groundwater runoff or its yield during the 30 driest days. To calculate the mass of salts dissolved in water, the volume of the groundwater runoff during the dry period was multiplied by TDS.
2. The impact of river water pollution on calculation results should be assessed in a differentiated way according to the amount and quality of wastewater discharged into the river for the points upstream and downstream the pollution sources (towns). Under Lithuanian conditions, this impact is not high, i.e. river water TDS values upstream and downstream the towns do not exceed $1-7 \%$. A similar range in the increase of chemical runoff might also be caused by the surface water pollution. A control indicator of subsurface chemical discharge determined from the minimum surface runoff is the TDS in the shallow and top confined aquifers within the river drainage zone.

3. Subsurface chemical discharge modulus ranges from 3-9 to $54 \mathrm{t} /$ year $/ \mathrm{km}^{2}$ in Lithuanian area and $15-54 \mathrm{t} / \mathrm{year} / \mathrm{km}^{2}$ in the Nemunas basin. The highest values of this modulus were determined in the basins of Merkys, Neris and Žeimena, where the groundwater runoff yields are considerably higher than in other basins.

4. Chemical runoff decrease in Central Lithuanian clayey plains depends mainly on groundwater runoff yield even at higher values of TDS in groundwater. In the North Lithuanian rivers (Mūša, Nemunèlis and Venta basins), notable for low values of groundwater runoff, the chemical discharge modulus (from 12 to $25 \mathrm{t} /$ year $/ \mathrm{km}^{2}$ ) grows due to higher TDS. Similar values of the chemi- 
cal discharge modulus were observed for the Maritime Plain and Žemaitija in the basins of the northern and western rivers (Minija and Bartuva).

5. The amount of dissolved solids brought out from the Lithuanian area by the rivers makes about $6.2 \mathrm{mln}$. $\mathrm{t}$ /year, including the chemical runoff from the subsurface reaching $2.2 \mathrm{mln}$ t/year. The major share of the subsurface chemical runoff is related to the Nemunas basin (46\%), while that from maritime rivers, Mūša and Venta basins range from several to $10 \%$.

6. In time, the regime of subsurface chemical discharge was substantially affected by technogenic load of the area in all Lithuania. Higher values of the chemical runoff observed at the beginning of the period (19852003) were caused by more intensive economic activities. Those river basins, where the technogenic effect did not change, showed the trend of stability in chemical runoff modulus (Mūša, Akmena-Danè, Šešupè); and on the contrary, the basins with a decline in this effect showed the trend of decrease or stability in chemical runoff modulus values (Šventoji, Merkys, Dubysa, Jūra, Nevèžis). For the Nemunas River water the chemical runoff modulus was rather stable during the whole period under study; thus, portraying a smoothing result of hydrochemical features of different basins.

\section{References}

Arustienè, J. 2006. Gruntinio vandens cheminè sudetis ir jos kaita [Shallow groundwater chemistry and its changes], Lietuvos požeminès hidrosferos monitoringas 2005 [Monitoring of subsurface hydrosphere in Lithuania 2005]. Lietuvos geologijos tarnyba, 21-28.

Arustienè, J. 2004. Požeminio vandens kokybès apžvalga [A review of groundwater quality], Lietuvos požeminès hidrosferos monitoringas 2003 [Monitoring of subsurface hydrosphere in Lithuania 2003]. Lietuvos geologijos tarnyba, 30-38.

Bagdžiūnaitè-Litvinaitienè, L. 2004. Dynamics of nutrient changes in the water of SE Lithuanian rivers for different periods of water level, Journal of Environmental Engineering and Landscape Management 12(4): 146-152.

Barisas, A. 1981. Minimalus Nemuno ir Neries nuotèkis [Minimum runoff of the Nemunas and Neris rivers], Geografijos metraštis 18: 127-139.

Diliūnas, J.; Karvelienè, D. 2004. Gruntinio vandens gamtinių (dinaminiu) išteklių ir cheminių medžiagų nuotèkio kaitos tendencijos ir prognoze [Trends and prognostication of changes in shallow groundwater natural (dynamical) resources and chemical runoff], in Lietuvos žemès gelmiu raida ir ištekliai [Evolution of earth crust and its resources in Lithuania]. Žurnalo "Litosfera” leidinys [publication of the 'Lithosphere' journal], 529-535.

Gailiušis, B.; Jablonskis, J.; Kovalenkienè, M. 2001. Lietuvos upés. Hidrografija ir nuotékis [Lithuanian rivers. Hydrography and runoff]. Kaunas: Energetikos institutas. 792 p.

Januškis, V. 1981. Lietuvos upiu minimalus nuotèkis šiltuoju laikotarpiu [The minimum runoff of Lithuanian rivers during the warm season]. Vilnius: Mokslas. $118 \mathrm{p}$.

Juodkazis, V.; Mikalauskas, V. 1994. Požeminio vandens slūgsojimo sąlygos [The groundwater occurrence condition], Lietuvos geologija 1994 [The geology of Lithuania]. Vilnius: Mokslo ir enciklopedijų leidykla. $447 \mathrm{p}$.
Kondratas, A. 2001. Antropogeninis poveikis Lietuvos gèlo požeminio vandens kokybei (1960-1995) [Anthropogenic impact on the quality of Lithuanian fresh groundwater (1960-1995)]. Vilnius. 195 p.

Lasinskas, M. 1994. Lietuvos upiu nuotékio tyrimai: bibliografija [Lithuanian river runoff investigations: bibliography]. Lietuvos Respublikos aplinkos apsaugos departamentas. Kaunas: Lietuvos energetikos institutas. 151 p.

Meilutytė-Barauskienė, D.; Kovalenkienè, M.; Irbinskas, V. 2008. Lietuvos upių vandens ištekliai klimato kaitos fone [Lithuanian river water resources at the background of climate changes], Geografija 44(2): 1-8.

Mičiudienè, V. 1991. Lietuvos hidrocheminis žemèlapis. Mastelis 1:50000 [The Hydrochemical Map of Lithuania]. Lietuvos geologijos tarnyba [Lithuanian Geological Survey]. Geologinis fondas [Geological Fund].

Pocienè, A.; Pocius, S. 2005. Content of nitrates in shallow groundwater depending on nature factors, Journal of Environmental Engineering and Landscape Management 13(1): 23-30.

Simniškaitė, I. 1968. Požeminių vandenų resursų nustatymas hidrografo skaidymu metodu šiaurès Lietuvos upèms [Determination of groundwater resources for the rivers of North Lithuania by hydrograph separating method], Hidrometeorologiniai straipsniai [Hydrometeorological papers]. T. 1: 257-266.

Tilickis, B. 2005. Vandens cheminès sudèties kaita Lietuvos baseinuose [Water chemistry variations in Lithuanian basins]. Klaipeda. $199 \mathrm{p}$.

Valstybinio upiu monitoringo duomenys. 2009 [National river monitoring data]. Environment Protection Agency [online]. 15-31 August 2009, Available from Internet: < website gamta.lt $>$.

Барисас, А. И.; Игнатавичюс, А. К. 1969. Подземный сток рек бассейна p. Нямунас в пределах Литовской ССР [Groundwater runoff into the Nemunas basin rivers within the area of Lithuanian SSR], Труды института геологии (Вильнюс) [Proceedings of the Institute of Geology (Vilnius)] 10: 3-25.

Кондратас, А. 1968. Изучение подземного стока бассейна p. Нямунас и условия взаимосвязи подземных и поверхностных вод. Ч. ІІ. Оченка подземного стока бассейна $p$. Нямунас гидрохимическим методом $и$ характеристика ионного стока в пределах Литовской $C C P$ [The study of subsurface runoff in the Nemunas River basin and conditions of relationship between the subsurface and surface waters. Pt. 2. The assessment of groundwater runoff in the Nemunas River basin by hydrochemical method and character of ion runoff within the area of the Lithuanian SSR]. Институт геологии (Вильнюс) [Institute of Geology (Vilnius)]. $59 \mathrm{c.}$

Кондратас, А. 1969. Оценка подземного стока бассейна p. Нямунас гидрохимическим методом [Assessment of groundwater runoff in the basin of the Nemunas River by hydrochemical method], Труды института геологии (Вильнюс) [Proceedings of the Institute of Geology (Vilnius)] 10: 61-68.

Многолетние данные о режиме и ресурсах поверхностных вод суши [Long-term data on the regime and resources of the surface waters]. 1987. T. VIII, Вып. 4. Ленинград: Гидрометеоиздат. 296 с.

Сакалаускене, Д. 1969. Динамические запасы и подземный сток [Dynamical reserves and groundwater runoff], Tpyды института геологии (Вильнюс) [Proceedings of the Institute of Geology (Vilnius)] 10: 53-60. 


\section{POŽEMINIS CHEMINIS NUOTĖKIS LIETUVOS TERITORIJOJE}

\section{J. Diliūnas, D. Karvelienė, A. Jurevičius}

Santrauka

Darbo tikslas - ivvertinti požemini cheminị nuotèkị Lietuvos hidrogeologinèmis sąlygomis, taikant klasikinę hidrologohidrogeologinę hidrografo skaidymo metodiką. Požeminis cheminis nuotėkis - tai druskų kiekis, nutekantis upėmis dęl drenažinio poveikio. Cheminį nuotèkį lemia du pagrindiniai veiksniai - požeminio nuotėkio debitas ir vandens bendroji mineralizacija. Požeminio nuotèkio modulio dydis (debitas iš $1 \mathrm{~km}^{2}$ ) Lietuvos teritorijos upių baseinuose kinta nuo 0,4 iki 5,0 l/s km². I upes požemiu nutekančio gruntinio vandens bendroji mineralizacija - nuo 180 iki 800 mg/l. Požeminio cheminio nuotèkio Lietuvos teritorijoje moduliai yra nuo 3-9 iki 54 t/metus iš 1 km². Didžiausias požeminis cheminis nuotėkis Baltijos aukštumose bei Dainavos lygumoje. Pastaraji dešimtmeti cheminis nuotèkis stabilizavosi dèl sumažejusios technogeninès apkrovos. Palyginti su bendru mineralinių medžiagu kiekiu, nutekančiu upèmis, požeminis cheminis nuotėkis gali sudaryti 7-45\%. Visas požeminis cheminis nuotèkis Lietuvos teritorijoje, ịvertintas pagal minimalų daugiametị nuotėkị ir to periodo upių vandens mineralizaciją siekia 2,2 mln. t/metus mineralinių medžiagu kurių apie 90 \% išplukdoma iš Nemuno baseino. Technogeninio užterštumo itakai požeminio cheminio nuotèkio vertinimo rezultatams riboti naudoti tik stebėjimų duomenys aukščiau taršos šaltinių (daugiausia miestų). Požeminio vandens cheminio nuotėkio, kurị lemia technogeninis poveikis, pokyčių kokybinis įvertinimas atliktas nuotėkio modulių grafoanalizės pagrindu.

Reikšminiai žodžiai: požeminio nuotèkio modulis, bendroji mineralizacija, požeminio cheminio nuotèkio modulis, gamtinės sąlygos.

\section{ПОДЗЕМНЫЙ ХИМИЧЕСКИЙ СТОК НА ТЕРРИТОРИИ ЛИТВЫ}

\section{Й. Дилюнас, Д. Карвялене, А. Юрявичюс}

Резюме

Целью работы было оценить подземный химический сток с использованием расчленения гидрографа рек и выноса химического материала в гидрогеологических условиях Литвы. Подземный химический сток - это количество солей, протекающих в речных водах из-за их дренажного воздействия. Химический сток зависит от двух основных факторов: дебита подземного стока и общей минерализации воды. Модуль подземного стока (дебит с 1 км$^{2}$ ) речных бассейнов в пределах Литвы меняется от 0,4 до 5,0 л/с с 1 км². Общая минерализация грунтовых вод, притекающих в реки, составляет 180-800 мг/л. Модули подземного химического стока в пределах территории Литвы имеют значения от 3-9 до 54 т/год с 1 км². Наибольший подземный химический сток наблюдается на терригории Балтийских высот и Дайнавской равнины. В последнее десятилетие химический сток стал более стабильным из-за уменьшающейся техногенной нагрузки. По сравнению с общим стоком минеральных веществ в реках подземный химический сток может составляет 7-45\%. Весь подземный химический сток, оцененный по минимальному многолетнему стоку и минерализации речной воды, составляет 2,2 млн. т/год минерального вещества, из которого 90\% поступает из бассейна р. Нямунас. Для уменьшения техногенного воздействия на результаты расчетов использованы данные химического состава воды только с постов наблюдения, расположенных выше источников загрязнения. Оценка изменения подземного химического стока выполнена графоаналитически с использованием изменения его модуля во времени.

Ключевые слова: модуль подземного стока, общая минерализация, модуль химического стока, природные условия.

Jonas DILIŪNAS. Dr, senior research worker, Groundwater Division, Institute of Geology and Geography. Research interests: groundwater resources and quality investigations, groundwater supply, draining, mineral of resources and construction sites. Publications: author of more than 200 scientific publications, 5 monographs.

Danute KARVELIENĖ. Research worker, Groundwater Division, Institute of Geology and Geography. Research interests: groundwater resources and quality investigations, undeground runoff. Publications: author of more than 10 scientific publications.

Arūnas JUREVIČIUS. Dr, head of Groundwater Division, Institute of Geology and Geography. Research interests: usage of groundwater resources, groundwater quality development. Publications: author of more than 30 scientific publications, 2 monographs. 